\section{Visión Electrónica Más que un estado sólido \\ https://doi.org/10.14483/issn.2248-4728}

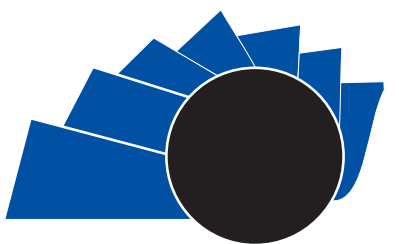

VISIÓN ELECTRONICA

A Research Vision

\title{
Breathing and temperature detection using thermal images in infants
}

\author{
Detección de respiración y temperatura con imágenes térmicas en bebés
}

\author{
Ana Carolina Rodríguez Cediel ${ }^{1}$, Ernesto Gómez Vargas ${ }^{2}$, \\ Oscar Julian Perdomo Charry ${ }^{3}$
}

\section{INFORMACIÓN DEL ARTICULO}

Historia del articulo

Enviado: 28/11/2018

Recibido: 03/12/2018

Aceptado: 25/12/2018

\section{Keywords:}

Breathing,

Sleep monitoring,

Sudden Infant Death Syndrome,

Temperature,

Thermal imaging.

Palabras clave:

Respiración,

Monitoreo del sueño,

Síndrome Infantil de Muerte

Súbita,

Temperatura,

Imágenes térmicas.

\begin{abstract}
Sudden Infant Death Syndrome (SIDS) is one of the leading causes of death in children under one year of age. SIDS is defined as the death of a child under one year of age, without apparent symptoms or causes during sleep that lead to his death. Therefore, monitoring of childhood sleep has become vital for parents, health care providers and health educators during the perinatal period. Temperature and respiration are the parameters most used during neonatal and postnatal consultations as an indicator of events related to the SIDS. This document proposes a method of non-invasive detection of temperature and breathing, based on the automatic detection of areas of the forehead, nose and mouth of the infant, calculating statistical measures and pixel-temperature conversion of thermal images. The proposed method used 7.189 thermal images of 6 infants during sleep, obtaining a general accuracy of $88,26 \%$ in temperature and breathing detection into three different classes.
\end{abstract}

\section{RESUMEN:}

El Síndrome Infantil de Muerte Súbita (SIMS) es una de las primeras causas de muerte en niños menores de un año. SIMS se define como la muerte de un niño menor de un año, sin aparente síntomas o causas durante el sueño que conllevan a su muerte. Por lo tanto, el monitoreo del sueño infantil se ha convertido en algo vital para los padres, los proveedores de atención médica y los educadores de salud durante el período perinatal. La temperatura y la respiración son los parámetros más usados durante las consultas neonatales y postnatales como indicador de eventos relacionados con el SIMS. En este documento se propone un método de detección no invasiva de temperatura y respiración, basado en la detección automática de zonas de la frente, nariz y boca del menor, cálculo de medidas estadísticas y conversión pixel - temperatura de imágenes térmicas. El método propuesto utilizó 7.189 imágenes térmicas de 6 menores durante el sueño, obteniendo una precisión general de $88.26 \%$ en la detección de temperatura y respiración en tres diferentes clases.

\footnotetext{
BSc. In Electronic Engineering, Universidad Distrital Francisco José de Caldas, Bogotá, Colombia. MSc. In Information and Communications. Universidad Distrital Francisco José de Caldas, Bogotá, Colombia. Current position: Research in Universidad Distrital Francisco José de Caldas, Bogotá, Colombia. E-mail: ancrodriguezc@correo.udistrital.edu.co. ORCID: https://orcid.org/0000-0002-8468-0212.

${ }^{2}$ BSc. In Electronic Engineering, MSc. In Information and Communications. Universidad Distrital Francisco José de Caldas, Bogotá, Colombia. Ph.D. In Engineering, Pontificia Universidad Javeriana, Bogotá, Colombia. Current position: Professor at Universidad Distrital Francisco José de Caldas, Bogotá, Colombia. E-mail: egomez@udistrital.edu.co. ORCID: https://orcid.org/0000-0003-4957-7313.

${ }^{3}$ BSc. In Electronic Engineering, Universidad Surcolombiana, Neiva, Colombia. MSc. In Engineering, Universidade Federal de Santa Catarina, Florianópolis, Brazil. Ph.D. (c) In Engineering, Universidad Nacional de Colombia, Bogotá, Colombia. Current position: Junior researcher in Universidad Nacional de Colombia, Colombia. E-mail: ojperdomoc@unal.edu.co. ORCID: https://orcid.org/O000-0001-9493-2324.

Cite this article as: A. C. Rodríguez-Cediel, E. Gómez-Vargas and O. J. Perdomo-Charry, "Breathing and temperature detection using thermal images in infants", Visión electrónica. algo más que un estado sólido, vol. 1, no. 2, Special edition, july-december 2018. DOI revista: https://doi.org/10.14483/issn.2248-4728
} 


\section{Introduction}

The Sudden Infant Death Syndrome (SIMS) is included within the general group of sudden and unexpected infant deaths (SIMI), defining as the process of death of an infant under one year, where there is no cause to justify his death. However, some research suggests that the death of the baby occurred by drowning or accidental suffocation [1-4].

Several researchers mention extrinsic and intrinsic factors related to the SIMS, such as: strangulation, asphyxia, accidental suffocation, overheating and other specific obstructions in breathing [3,5,6]. Based on the above, the temperature and breathing parameters were selected in this research under medical criteria as two variables to monitor the infant during sleep.

SIDS is the third cause of death in infants and the most common among children one month and one-year-old [8]. "Safe Sleep", the death rates caused by the Sudden Infant Death Syndrome continue to be constant [7-10]. The statistics of infant mortality reported by the National Administrative Department of Statistics or abbreviated in Spanish as DANE shown an increase in death rates due to accidental suffocation and asphyxia, concluding that one infant died every three days in the city of Bogotá [11].

Additionally, some researchers have proposed algorithms to detect and to monitor vital signs with images and signals. However, the measurement of the arterial pulse, heart rate and respiration through of images is not an easy task [12-15]. Thermography is a non-invasive technique, which provides information on physiological processes by examining the temperature distributions of the skin and organs.

Thermography have been used as a complementary tool for anatomical investigations, due to it reveals some problems not revealed by anatomical exams [16]. On the other hand, thermography offers real-time temperature measurement, where a single image may represent several thousand temperature points, recorded in a fraction of a second [17]. Abbas et al. proposed a real-time-neonatal breathing monitoring model based on infrared thermography validated with a minor from the Intensive Care Unit (ICU) [12,18]. However, monitoring the behavior of the infant while sleeping focused on breathing and temperature need to be researched using a larger number of infants to define warning signs [18].

Thermography is an integral part of the development of this research, which led to the construction of a database of thermal images of 6 children under one year of 7,189 images, acquired with a IR OPTRIS PI450 thermal camera, with thermal sensitivity (NETD) of $40 \mathrm{mK}$, an FPA type detector, uncooled ( $25 \times 25 \mu \mathrm{m})$, an optical resolution of $382 \times 288$ pixels, a spectral range of $7.5-13 \mu \mathrm{m}$, a temperature range of $-20^{\circ} \mathrm{C}$ up to $900^{\circ} \mathrm{C}$, the frequency of the image of $80 \mathrm{~Hz} / \mathrm{sec}$ and characterized with a lens at $1000 \mathrm{~mm}$ [19]. This study has the methodological concept of the Ministry of Health and the informed consent of the parents of the minors.

The main focus of this work is to be able to apply thermal image processing techniques within the medical and biological area, to a public health problem with reference to the Sudden Infant Death Syndrome (SIMS) [20]. In this way, the objective is to develop a non-invasive model for the detection of some extrinsic risk factors, including temperature and breathing. The document is organized as follows: Section 2 illustrates the proposed methods of processing, architecture and methodology, on the detection of temperature and respiration based on thermal images. Section 3 shows the flow diagram of the proposed approach to detecting temperature and respiration, describing and extracting the characteristics of the images. Section 4 provides the experimental results and finally, the document concludes in section 5 .

\section{Methods}

Figure 1 describes through a block diagram of the noninvasive detection of temperature and breathing. The diagram contains a block with the acquisition of the image with the software PI Connect; a second block with the image processing algorithms; two blocks related with the Region of Interest (ROI) detection and two finals blocks calculating the temperature and breathing inside the ROIs.

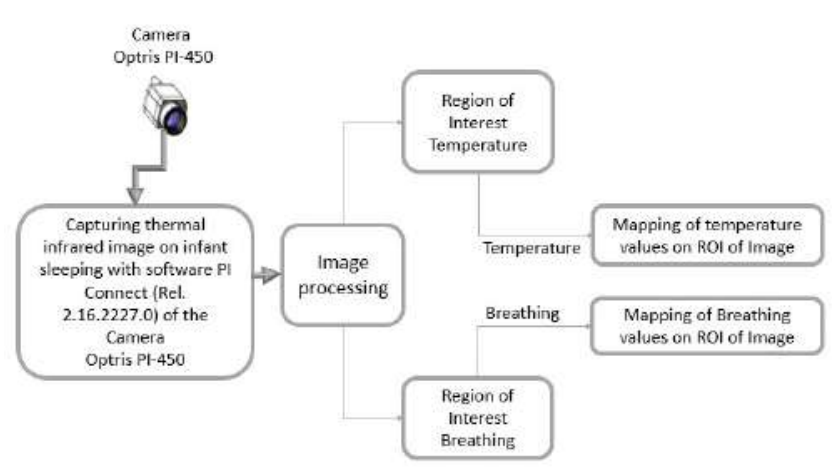

Figure 1. Block diagram with the proposed model for non-invasive detection of temperature and breathing. Source: own. 


\subsection{Curve fitting of pixel intensity and temperature values}

Two images of infants are shown in Figure 2. The preprocessed in gray scale with the coordinates [x,y], and the two unprocessed thermal images with the corresponding temperature values in centigrade for the coordinate $[\mathrm{x}, \mathrm{y}]$. We obtained 30 random points of the infant's face with a temperature range between $29^{\circ} \mathrm{C}$ and $36^{\circ} \mathrm{C}$, in order to calculate a characteristic equation to convert pixel in ${ }^{\circ} \mathrm{C}$.

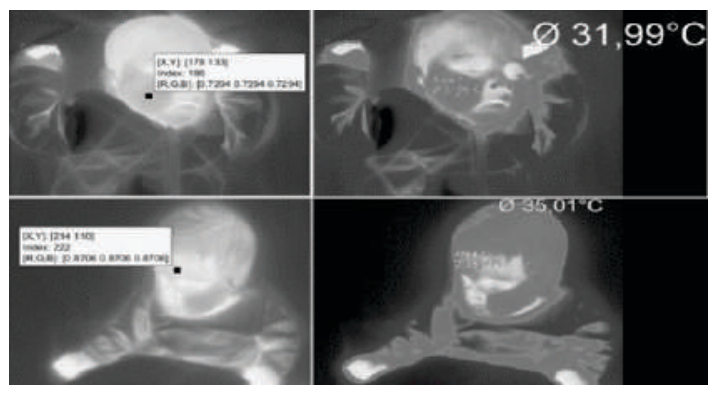

Figure 2. Pixel intensity ratio in gray scale with respect to temperature of the thermal camera. Source: own.

A subset with 30 points was used to characterize the thermal images. The characterization was performed using a curve fitting among the equivalence in the range of pixels of the captured image and the equivalent temperature range. A characteristic equation of polynomial type was chosen, because it offers the best curve-fitting for the values with minimal error, as presented in Figure 3.

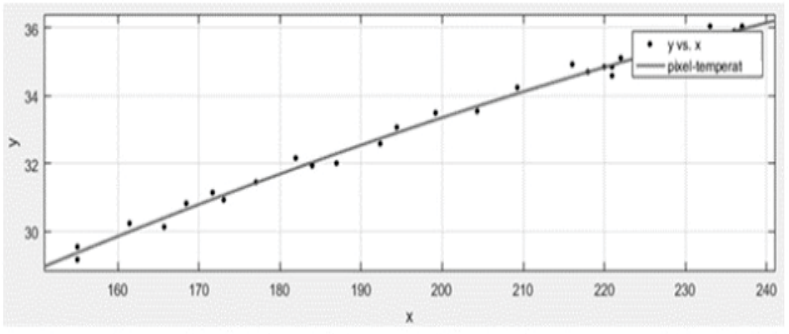

Figure 3. Polynomial curve for the gray scale pixel values against temperature values. Source: own.

The reported curve is the result of the adjustment of the curve of the points plotted with respect to a polynomial equation of second degree. The characteristic equation is reported in Equation 1.

$\mathrm{Y}=(-0.0002191) \mathrm{X}^{2}+(0.1665) \mathrm{X}+8.814$
On the other hand, the Sum of the Squared Errors of predictions (SSE), which corresponds to the sum of the squares of the residuals (predicted deviations of the real empirical values of the data) was 0.7553 and the Root Mean Squared Error (RMSE) or standard deviation of the residuals (prediction errors) was 0.2173 . The best fitting curve was chosen because it presents the lowest error and a coefficient of determination R2 and R2-adjusted of 0.9913 and 0.9902 respectively, as presented in Figure 4.

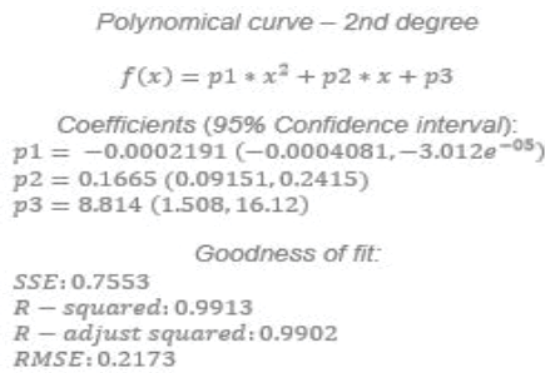

Figure 4. Goodness of fit for the polynomial second degree equation. Source: own.

The application of most common techniques for the processing of thermal images, seek to improve the quality of the images and even highlight the details that are interested in the specific parts of the image. The equalization of the initial histogram is used in order to achieve an ideal histogram, where a coverage of the range of [0.255] is defined, the objective of the equalization is that the image has a uniform distribution over the entire gray scale. As a result of this process, an image with a greater dynamic range is obtained and which has greater contrast.

Likewise, the new intensity values of the occurrence probability function are calculated and then, intensities are replaced in Equation 2, as follows:

$$
S_{K}=\left[\Sigma_{j}^{K}=0^{\mathrm{N}]}\right] \frac{\mathrm{x} \text { maximum intensy level }}{\text { number of pixels }}
$$

\subsection{Temperature and breathing detection}

The detection of the foreground (relevant information) and background (not relevant information) was performed using a thresholding and a binarization to the image. The relevant information in the image was highlighted and the image was split into four parts, where the ROIs 2 and 3 belonged to the extraction regions of characteristics of the values of temperature in forehead and breathing in nose and mouth as presents in Figure 5. 


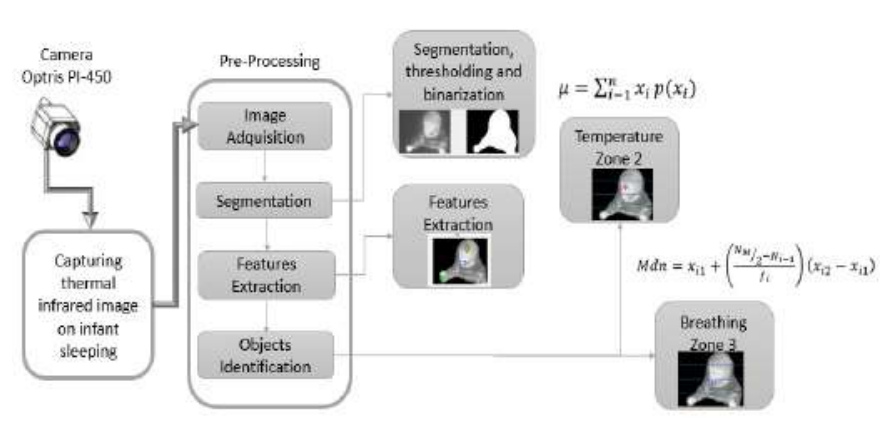

Figure 5. Block diagram of proposed method with acquisition, pre-processing and algorithms to measure temperature and breathing in infants. Source: own.

The number of pixels in each intensity level was obtained with the histogram and its corresponding equalization. The thresholding and binarization techniques help to extract features in the 4 ROIs within the picture. The values corresponding to the regions of interest 2 and 3 corresponding to temperature and breathing respectively, are calculated using equations 3 and 4:

The temperature is calculated as the mean or expectation of a discrete random variable, where $X_{i}$ represents all possible values of the variable and $p(X i)$ the probabilities of each of these values, as shown in Equation 3:

$$
\mu=\sum_{i-1}^{n} x_{i} p\left(x_{i}\right)
$$

The breathing is defined as the median of a grouped dataset. Where is the position of the median; is the cumulative frequency of the pre-median class; is the absolute frequency of the class of the median and $\left(x_{i 2}-x_{i 1}\right)$ is the amplitude of the interval of the class of the median, as reported in Equation 4.

$$
M d n=x_{i 1}+\left(\frac{N_{M} / 2-N_{i-1}}{f_{i}}\right)\left(x_{i 2}-x_{i 1}\right)
$$

\section{Experimental Setup}

The interface between that heat production and the environment is the organ of the skin. This dynamic organ is constantly adjusted to balance internal and external conditions, while satisfying the physiological demands of the organism, so the emissivity value was set to 0.98 for the human skin.

This study followed all the ethical requirements for non-invasive studies with infants, and with each of the informed consent of the parents. The capture of the images was based on the visualization and analysis of the measurement environment where the child was sleeping.

The images collected for this research was 13.886 images, with a configuration of the PI-Connect software for the Iron and Rainbow palettes. Figure 6 presents a same infant with different palettes used to collect the images.

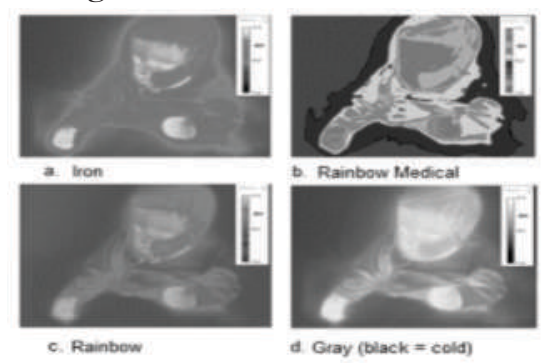

Figure 6. Color-maps for thermal images captured with PI-Connect Software. Source: own.

The measurements were made under different environments and different focal distances, without affecting the position and without imposing conditions on the position of the minor, in order to have the best approximation to the real environment. The acquired images are a 3dimensional matrix of $<288 \times 382 \times 3>$ of TIFF format (Tag Image File Format), which were processed using the MATLAB software. The images were treated as a matrix whose indexes of rows and columns identify a specific point of the image, each of these points have a value within a range of $[0,255]$ interpreted as discrete data, which give value to each of them. The channels of the photo (RGB). Table 1 reports the number of captured images for each color-map with the recording time.

\begin{tabular}{|c|c|r|r|r|r|r|}
\hline SUBJECT & AGE & $\begin{array}{c}\text { NUMBER OF } \\
\text { SAMPLES }\end{array}$ & IRON & RAINBOW & OTHERS & (t) $\mathbf{~ s g} 4$ \\
\hline INFANT A & 6 MONTHS & 2.305 & 505 & 1.800 & 0 & $2.305 \mathrm{sg}$ \\
\hline INFANT B & 9 MONTHS & 1.345 & 651 & 586 & 108 & $1.345 \mathrm{sg}$ \\
\hline INFANT C & 5 MONTHS & 87 & 87 & 0 & 0 & $3.600 \mathrm{sg}$ \\
\hline INFANT D & 1 MONTH & 3.340 & 1.670 & 1.670 & 0 & $3.340 \mathrm{sg}$ \\
\hline INFANT E & 4 MONTHS & 3.083 & 1.542 & 1.541 & 0 & $3.083 \mathrm{sg}$ \\
\hline INFANT F & 12 MONTHS & 3.726 & 2.734 & 560 & 432 & $3.726 \mathrm{sg}$ \\
\hline \multicolumn{2}{|c|}{ TOTAL } & 13.886 & 7.189 & 6.157 & 540 & $17.399 \mathrm{sg}$ \\
\hline
\end{tabular}

Table 1. Number of images obtained with Iron, Rainbow and other color-maps with the total recording time. Source: own. 


\section{Results}

The normal temperature ranges were taken, for the two ROIs, in order to make a comparison of temperature and respiration, determining if the two values are normal, regular or inadequate range, compared to what the PI-Connect software of the optris camera shows as described in Section 2 .

A detailed analysis of the results obtained was done through a $3 \times 3$ confusion matrix, which represents the level of accuracy between the temperature and breathing ranges of the minor during sleep given by the infrared thermography sensor and the predictions given by the proposed algorithm.

In Table 2, the main diagonal is observed which represents the agreement given by the PI-Connect software and the prediction of the proposed algorithm, the bold values indicate the precision and completeness of the model. The kappa coefficient was also calculated, which is based on comparing the agreement observed in a set of data, with respect to what could happen by mere chance.

\begin{tabular}{|c|c|c|c|c|c|}
\hline & \multicolumn{3}{|c|}{$\begin{array}{c}\text { MEASURES OBTAINED BY SOFTWARE PI } \\
- \text { - CONNECT }\end{array}$} & \multirow[b]{2}{*}{$\begin{array}{l}\text { Classification } \\
\text { overall }\end{array}$} & \multirow[b]{2}{*}{$\begin{array}{l}\text { Producer } \\
\text { Accuracy } \\
\text { (Precision }\end{array}$} \\
\hline & $\begin{array}{c}\text { Temperature } \\
\text { And } \\
\text { Breathing } \\
\text { Inadequate }\end{array}$ & \begin{tabular}{|l} 
Temperature \\
And \\
Breathing \\
Regular
\end{tabular} & $\begin{array}{c}\text { Temperature } \\
\text { And } \\
\text { Breathing } \\
\text { Normal }\end{array}$ & & \\
\hline \begin{tabular}{c|c} 
& Temperature \\
And \\
And \\
Breathing \\
Inadequate
\end{tabular} & 900 & 178 & 106 & 1184 & $76,014 \%$ \\
\hline 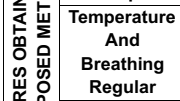 & 154 & 2566 & 102 & 2822 & $90,928 \%$ \\
\hline \begin{tabular}{|c|c}
$\begin{array}{c}\text { Temperature } \\
\text { And } \\
\text { Breathing } \\
\text { Normal }\end{array}$ \\
\end{tabular} & 178 & 126 & 2879 & 3183 & $90,449 \%$ \\
\hline $\begin{array}{l}\text { Truth } \\
\text { overall }\end{array}$ & 1232 & 2870 & 3087 & 7189 & \\
\hline $\begin{array}{c}\text { User } \\
\text { Accuracy } \\
\text { (Recall) }\end{array}$ & $73,052 \%$ & $89,408 \%$ & $93,262 \%$ & & \\
\hline $\begin{array}{l}\text { Overall } \\
\text { Accuracy }\end{array}$ & $88,26 \%$ & & & & \\
\hline Kappa & 0,812 & & & & \\
\hline
\end{tabular}

Table 2. Confusion matrix and performance measures obtained by predicting the temperature and breathing values compared to Software PI-Connect by Optris.

Source:own.

Based on the literature, the kappa coefficient defines values " $<0$ " as indicative of non-agreement and "O $0,20 "$ as a slight concordance, "0,21 -0,40" fair agreement, "0,41 - 0,60" moderate agreement, "0,61 0,80 " substantial match, and "0,81 - 1" almost perfect match. The kappa coefficient obtained was 0,812 , which indicates an almost perfect concordance.

\section{Discussion and Conclusion}

The normal temperature ranges were determined, which correspond to the temperature of the skin in the first area of interest of the image and the normal temperature ranges related to respiration, which belong to the second area of interest of the image. The proposed model has the ability to store sudden events, episodes that can define the causes of sudden death or at least changes related to the temperature and breathing of a child while asleep.

Otherwise, this research allows observe that the temperature ranges in the infant $\mathrm{A}$, the temperature varies according to the position in which it is sleeping, in the same way these ranges can be affected when the child presents strong movements or when the baby cries, how it was presented during the investigation. Additionally, it was determined that the temperature in babies is not as stable as it should be, they just lie down.

The use of the proposed model for several days in children or even a deep examination of thermography, could help in the definition of a clinical parameter that stratifies the risk in neonates. The definition of warning signs and previous diagnosis continues to be an engineering challenge, therefore, a study with a greater number of minors is required to reinforce this hypothesis.

\section{Acknowledgments}

Ana Rodríguez thanks "Centro de Investigaciones y Desarrollo Científico" of Universidad Distrital Francisco José de Caldas for funding this research with a financial support at the moment of buying a camera reference optris PI-450.

\section{References}

[1] CDC, "Sudden Unexpected Infant Death and Sudden Infant Death Syndrome," 2014. [O n l i n e ]. A v a i l a ble a t : https://www.cdc.gov/sids/index.htm.

[2] E. A. Nelson, B. J. Taylor and I. L. Weatherall, "Sleeping Position and Infant Bedding May Predispose to Hyperthermia and the Sudden Infant Death Syndrome", The Lancet, vol. 333, no. 8631,1989 , pp. $199-201$. https://doi.org/10.1016/So1406736(89)91211-7.

[3] GEMPSI de la AEP, "Síndrome de la Muerte Súbita del Lactante (SMSL) LIBRO BLANCO 2 $2^{a}$ edición”, 2003. [Online]. Available at: https://www.ascalema.es/wpcontent/uploads/2014/10/Grupo-de-Trabajode-AEP.-Muerte-S\%C3\%BAbita-del-LactanteSMSL.-Libro-Blanco.2003.pdf. 
[4] G. Q. González, M. B. Porras and N. S. Tenorio, "Muerte Súbita del Lactante”, Med. Leg. Costa Rica, vol.33, no. 1, 2016, pp. 44-56.

[5] M. L. Latorre Castro, G. P. Fernández Deaza and S. Ucrós Rodríguez, "Síndrome Infantil de Muerte Súbita: nuevos conceptos y una misma solución”, Rev. la Fac. Med., vol. 62, no. 2, 2014, p p. $247-254$

https://doi.org/10.15446/revfacmed.v62n2.45 $\underline{415}$.

[6] A. L. Ponsonby, T. Dwyer, L. E. Gibbons, J. A. Cochrane and Y. G. Wang, "Factors Potentiating the Risk of Sudden Infant Death Syndrome Associated with the Prone Position”, N Engl J Med., vol. 329, no. 6, 1993, pp. 377-382. https://doi.org/10.1056/NEJM199308053290 $\underline{601}$.

[7] R. Y. Moon and L. Fu, "Sudden infant death syndrome: An update", Pediatr. Rev., vol. 33, no. $7, \quad 2012, \quad$ p p. $\quad 314-320$. https://doi.org/10.1542/pir.33-7-314.

[8] SCP, "Fundación Santi un Milagro de Vida", 2012 . [O n line $]$. A v a i l a ble a t

http://www.prevencionmuertesubitainfantil.org.

[9] Medlineplus, “MedlinePlus Medical Encyclopaedia. U.S. National Library of Medicine and National Institutes of Health", 2017 . [Online]. Available at: https://medlineplus.gov/spanish/news/fullsto ry $169461 . \mathrm{html}$.

[10] M. Hackett and H. Simons, "Parental Adherence to Infant Sleep Safety Recommendations," J. Community Med. Health Educ., vol. 3, no. 4, 2013. https://doi.org/10.4172/2161-0711.1000219.

[11] M. L. Latorre Castro, C. Carrascal Gordillo and C. Zambrano Pérez, "Síndrome infantil de muerte súbita : el riesgo que afrontan los lactantes en Bogotá, D. C., Colombia”, Rev. la Fac. Med., vol. 64, no. 4, 2016, pp. 665-670. https://doi.org/10.15446/revfacmed.v64n4.54 $\underline{801}$.

[12] A. K. Abbas, K. Heimann, K. Jergus, T.
Orlikowsky and S. Leonhardt, "Neonatal noncontact respiratory monitoring based on realtime infrared thermography”, Biomed. Eng. Online, vol. 10, no. 1, $2011, \mathrm{p}$. 93.

https://doi.org/10.1186/1475-925X-10-93.

[13]

S. Y. Chekmenev, H. Rara and A. Farag, "Noncontact, Wavelet-based Measurement of Vital Signs using Thermal Imaging”, 2005, pp. 25-30.

S. Y. Chekmenev, A. Farag and E. A. Essock, "Multiresolution approach for non-contact measurements of arterial pulse using thermal imaging”, Proc. IEEE Comput. Soc. Conf. Comput. Vis. Pattern Recognit., 2006. https://doi.org/10.1109/CVPRW.2006.139.

[15] T. R. Gault and A. Farag, "A Fully Automatic Method to Extract the Heart Rate from Thermal Video", IEEE Conference on Computer Vision and Pattern Recognition Workshops, 2013 , pp. $336-341$. https://doi.org/10.1109/CVPRW.2013.57.

[16] B. F. Jones and P. Plassmann, "Digital infrared thermal imaging of human skin”, vol. 21 , no. 6 , 2002 , pp. $41-48$.

https://doi.org/10.1109/MEMB.2002.117513 $\underline{7}$.

[17] E. F. Ring and K. Ammer, "Infrared thermal imaging in medicine”, Physiol Meas., vol. 33, no. 3, 2012. https://doi.org/10.1088/09673334/33/3/R33.

[18] C. Li and L. Bi, "Intelligent Recognition Method of Infant Sleeping Position Based on Thermal Infrared Imaging”, International Journal of Control and Automation, vol. 8, no. 7, 2015, pp. 133-140.

[19] Optris PI-450, "Calculador óptico", 2017. [O n l i n e ]. A v a il a ble a t : http://www.optris.es/calculador-optico.

[20] M. L. Latorre and C. Zambrano, "Muerte Súbita Infantil (MSI): un problema de salud pública en Colombia”, 2016. [Online]. Available at: https://scp.com.co/editorial-boletin/muertesubita-infantil-msi-un-problema-de-salud- 